Western University

Scholarship@Western

Aboriginal Policy Research Consortium International (APRCi)

3-2004

Fishing Lifestyles: 'Territorians', Traditional Owners and the Management of Recreational Fishing in Kakadu National Park

Lisa Palmer

Follow this and additional works at: https://ir.lib.uwo.ca/aprci

Part of the Environmental Policy Commons

Citation of this paper:

Palmer, Lisa, "Fishing Lifestyles: 'Territorians', Traditional Owners and the Management of Recreational Fishing in Kakadu National Park" (2004). Aboriginal Policy Research Consortium International (APRCi). 209.

https://ir.lib.uwo.ca/aprci/209 


\title{
Fishing Lifestyles: 'Territorians', Traditional Owners and the Management of Recreational Fishing in Kakadu National Park
}

\author{
LISA PALMER, University of Melbourne, Australia
}

\begin{abstract}
The relationships between traditional Aboriginal land owners and other Park users in Kakadu National Park in the Northern Territory are characterised by competing agendas and competing ideas about appropriate ways of relating to the environment. Similarly, the management of recreational fishing in the Park is permeated by the tensions and opposition of contested ideas and perspectives from non-Aboriginal fishers and Aboriginal traditional owners. The local knowledge and rights of 'Territorians' [non-Aboriginal Northern Territory residents] are continually pitted against the local knowledge and rights of Aboriginal traditional owners. Under these circumstances, debates between non-Aboriginal fishers and Aboriginal traditional owners are overwhelmingly dominated by the unequal power relationships created through an alliance between science and the State. The complex and multi-dimensional nature of Aboriginal traditional owners' concerns for country renders these concerns invisible or incomprehensible to government, science and non-Aboriginal fishers who are each guided by very different epistemic commitments. It is a state of affairs that leaves the situated knowledge of Aboriginal traditional owners with a limited authority in the nonAboriginal domain and detracts from their ability to manage and care for their homelands.
\end{abstract}

KEY WORDS Recreational fishing; Aborigines; national parks; joint management; nature; natural resource management

\section{ACRONYMS}

AFANT Amateur Fishermen's Association of the Northern Territory

ALRA Aboriginal Land Rights (Northern Territory) Act 1976 (Cth)

ANCA Australian Nature Conservation Agency

ANPWS Australian National Parks and Wildlife Service

KNPBoM Kakadu National Park Board of Management 


\section{Introduction}

Fishing is an activity enjoyed in Kakadu National Park by Aboriginal and non-Aboriginal residents and Park visitors alike. Of this latter group, it is a particularly popular activity with Northern Territory Park users from Darwin and Katherine where fishing is asserted to be integral to the 'Territory Lifestyle'. In 1999, in an advertisement in the Sunday Territorian, the Northern Territory Government identified six key areas 'that will underpin its policies, plans and actions into the 21st Century' (31 October 1999, 42). The first key area to be listed was to 'Preserve and Build on the Lifestyle of all Territorians' and featured a colour photograph of two such 'Territorians' proudly holding up their barramundi catches in a remote river location. A major goal identified in this key policy area was to ensure 'our natural environment is largely undisturbed and readily accessible to the public' (Northern Territory Government, 1999, 42). No reference was made to the fact that more than $50 \%$ of 'our natural environment' and over $80 \%$ of the Northern Territory coastline is held under inalienable Aboriginal freehold title under the terms of the Aboriginal Land Rights (Northern Territory) Act 1976 (Cth) ('ALRA'). In 1998, the Northern Territory Government placed a similar advertisement in the Sunday Territorian (Northern Territory Government, 1998, 12) promoting the need for Northern Territory Statehood to protect the 'Territory Lifestyle'. This advertisement was critical of Parks Australia, a Canberra bureaucracy, which controls fisheries management in Kakadu National Park (Figure 1). Recreational fishing in the Northern Territory is a politically emotive issue and, prior to the Country Liberal Party losing office in 2001, it was an integral part of the Government's strategy to expand its control and management of the Territory's land and natural resource base.

In this paper, the differing frameworks of knowledge, language and power that constitute particular fishing practices are examined from the perspectives of non-Aboriginal fishers and local Aboriginal traditional owners or Bininj (a Gundjeihmi and Kunwinjku word which can mean man, male, person or Aboriginal people depending on context) in Kakadu National Park. It is shown that, while the agenda of the 'Territory Lifestyle' is supported by the discourse of science and 'best practice' fisheries management, fishing is also an activity integral to the Bininj lifestyle in Kakadu National Park. In this way fishing in Kakadu is an issue about which the local knowledge and rights of 'Territorians' are continually pitted against the local knowledge and rights of Bininj. Considerable controversy was created over this issue when the 1996 Kakadu National Park Draft Plan of Management (KNPBoM and ANCA, 1996) proposed additional restrictions on access for recreational fishing in the Park. In the debate that ensued, the issue became one of contested knowledges between non-Aboriginal fishers and conservation science on the one hand, and, on the other, Bininj knowledge and management of the resource base. It was a debate that revolved around who has the right to make decisions on resource and land use. In 1997, the conflict between these two 'local' knowledges and agendas was the source of a heated public campaign waged by the recreational fishing lobby in the Northern Territory. These fishers argued that proposed changes by the Kakadu Board of Management to fishing access in Kakadu National Park were unacceptable without scientific proof, such as a proven decrease in barramundi stocks, to validate the decisions being made. These objections received considerable support from both Northern Territory and Federal politicians.

From the perspective of Bininj, these decisions about fishing management in the Park encompassed broader issues than a concern over the health of barramundi stocks. However, the power of the State in the support of the discourse of conservation science acted to obscure the complexities of a situation characterised by differences in cultural values and constructions of knowledge. This unequal power relationship created though an alliance between science and the State leaves the situated knowledge of Bininj with a limited field of authority in the nonAboriginal domain. Moreover, the complex and 


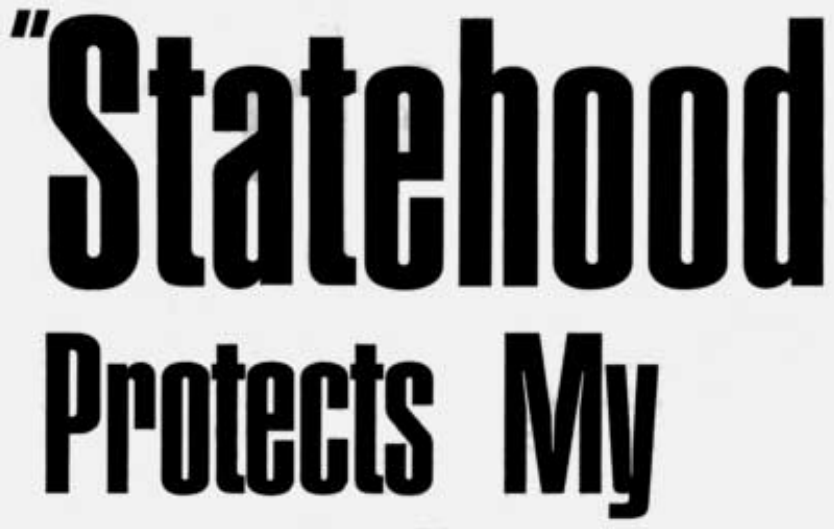

lifesty|le"

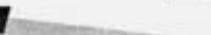

Like your fishing? Reckon it's our right to cast a lure?

Imagine if the Senate in Canberra decided to set the bag limit for barra and told us we shouldn't catch as many fish.

Unless we become a State, there is nothing to stop the Commonwealth Parliament from forcing ndiculous laws on

Territorians.

Canberra already imposes a smaller barra bag limit in the Commonwcalth controlled Kakadu National Park than exists at nearby Corroboree Billabong.

Becoming a State means our own laws, such as the Northern Territory's Barramundi Management Plan, cannot be over-ruled by Canberra.

At the moment Territorians don'r have the same rights as the rest of Australia.

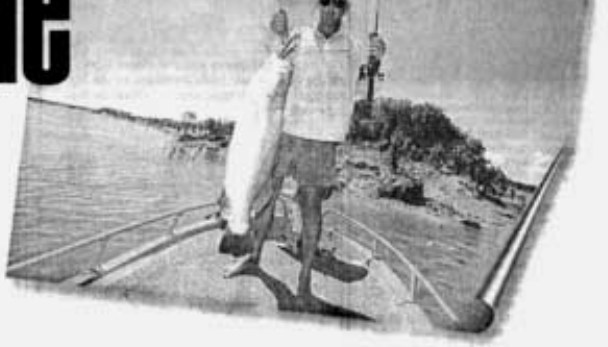

Your rights can be taken away by Canberra with the stroke of a pen.

They've done it once. There is nothing to stop them from doing it again.

Except Statchood.

Statehood means your rights are protected from any more interference from Canberra. Statehood means equality with other Australians. Nothing more. Nothing less.

Do your bit for the Territory lifestyle in the referendum!
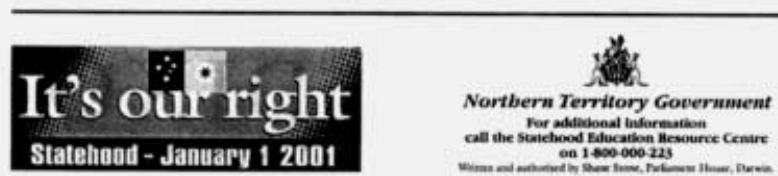

Figure 1 'Statehood Protects My Lifestyle' (Source: Northern Territory Government advertisement in the Sunday Territorian, 6 September 1998, 12. Courtesy of the Northern Territory News). 
multi-dimensional nature of Bininj concerns for country, a term which refers to the collective identity shared by a group of people, their land (and sea) estate and all the natural and supernatural phenomena contained within that estate, renders these concerns invisible or incomprehensible to government, science and fishers who are guided by a very different set of epistemic commitments. The responses from the fishing public to proposals to curtail their activities in Kakadu National Park and the subsequent revision of these proposals by local Aboriginal traditional owners frame the analysis of this paper. It is an analysis that demonstrates, from a particular vantage point, the discursive, institutional and practical impediments and pressures experienced by Aboriginal traditional owners in their attempts to manage Kakadu National Park according to practices and priorities relevant to the Bininj jurisdiction. The paper is not an attempt to survey or ascertain the success or otherwise of particular fisheries management regimes. While the issue of sustainable management is important to both non-Aboriginal fishers and Bininj, the aim of this paper is to draw attention to the politics and power relations that ensure the ontological and epistemological dominance of a non-Aboriginal regime of fisheries resource management in Kakadu National Park. The paper moves beyond an understanding of natural resource management as a set of practices based around a concept of 'nature' as $a$ priori, to an elucidation of the 'epistemological questions of authority, speaking positions, and the negotiation of reality and power' (Christie and Perrett, 1996, 57) that permeate the disparate yet entwined systems of Bininj and nonAboriginal land and resource management in Kakadu National Park. The paper is based on fieldwork and interviews which the author carried out in Kakadu National Park between 1997 and 1999 (Palmer, 2001).

\section{Kakadu National Park}

The famed 'wilderness' area, Kakadu National Park in the Northern Territory, was invented in 1978. It was created by the Commonwealth
Government after the Ranger Uranium Environmental Inquiry recommended that a jointly managed national park be established as a land use strategy which could balance the competing interests of Aboriginal land rights, uranium mining and an influx of non-Aboriginal people into the region. Stage One of Kakadu National Park was the first successful land claim to be granted under the ALRA. The claim was granted on the condition that the land be immediately leased back to the Commonwealth as a national park. While only $50 \%$ of the Park area is currently Aboriginal land under the ALRA, the terms of the Park lease agreement stipulate that the whole park must be managed as Aboriginal land, and current land claims are attempting to establish a legal basis for this recognition. The Park is managed under a joint arrangement between the Kakadu Board of Management, with a majority of the Board members being Traditional Aboriginal Owners, and Parks Australia, a section of Environment Australia (now the Department of Environment and Heritage), the Commonwealth department responsible for the environment portfolio. The lease agreement that establishes the Park provides for an Aboriginal majority on the Kakadu Board of Management, Aboriginal involvement in and employment in the Park service itself, and establishes the access rights and responsibilities of visitors to the Park. Statutory authority is vested in the office of the Director of National Parks and Wildlife.

A fluctuating population of approximately 500 Aboriginal people lives within the Park and the Aboriginal traditional owners, of whom there are approximately 120 in Kakadu, are recognised under Australian statute (the ALRA) as owning approximately half the area of the National Park. Kakadu National Park is comprised of approximately twenty clan estates and forms a meeting point for Aboriginal people from three cultural blocs to the east, west and south. These blocs have different land tenure systems and languages and are influenced by their own particular social histories (Keen, 1975; Chaloupka, 1975; Keen, 1980; Levitus, 1982; Merlan and Rumsey, 1982). 
The 1998 Kakadu National Park Plan of Management states that Kakadu is 'an Aboriginal place'. This reference indicates recognition of the Kakadu area as a living Aboriginal landscape. As opposed to an interpretation of this place as a natural landscape or a wilderness, it is represented in the Park's official documentation as a place that has been, and continues to be, lived in, interacted with and managed by its Aboriginal traditional owners.

In reality, Kakadu National Park is constructed by ideas of place and identity circulating within and between at least two domains (Palmer, 2001). In the Aboriginal domain, the area is a series of contiguous customary estates. The interrelationships between them form a complex pattern of relatedness and differentiation that constitute local Aboriginal identification with place. For the Aboriginal traditional owners, Aboriginal customary law is the foundation on which their relationships to their country and to each other rely. It is a system of law that both emplaces people and establishes a basis for broader social relationships in the region. According to local customary law, it was Ancestor beings who made known to these people their social and physical universe, and who gave each clan [local descent group] place-specific language to relate to their country. People belong to their country and it is their responsibility to maintain it according to local customs and traditions for future generations (Chaloupka et al., 1985; Chaloupka, 1993).

Kakadu National Park is also a famous tourist destination in Australia and receives in excess of 230000 domestic and international visitors per year. In the non-Aboriginal domain of tourism, Kakadu exists as a discrete tract of land which people want to experience for its World Heritage listed natural and cultural values, and as a representative part of Australia's heritage. Over the past two decades it has become one of Australia's most famous national parks, a premier nature lovers' destination. In 1986, the Kakadu National Park Plan of Management stated that $37 \%$ of all private visitors brought fishing gear with them to the park, while $12 \%$ brought a boat
(ANPWS, 1986, 124). However, by the early 1990s, the relative importance of recreational fishing compared with visitor interest in other activities appeared to be declining (ANPWS and Kakadu National Park Board of Management, 1991, 30). Despite the fact that most visitors to the Park are now attracted by non-fishing activities, local and interstate fishers continue to view Kakadu National Park as an important area for recreational fishing. The region contains four major rivers, the South, East and West Alligator and the Wildman River. Fishing effort is concentrated on the South and East Alligator systems (Duff, 1989). The majority of non-Aboriginal fishers target barramundi as their preferred species.

\section{Fishing controversy and the 1996 Kakadu} National Park Draft Plan of Management

Since 1991 the areas upstream of the Kakadu Highway, along with the West Alligator River, have been closed to recreational fishing (Figure 2). The 1996 Kakadu National Park Draft Plan of Management proposed further controls and restrictions in relation to fishing and boating in Kakadu National Park. These included the need to obtain permits for boating in the lower reaches of the East and South Alligator River, a ban on fishing in the area of the East Alligator upstream from Cahill's Crossing, a ban on fishing competitions, and a reduction of the bag limit for barramundi from five to two fish per person.

The reasons given in the Draft Plan for these proposed changes and restrictions on boating access to other areas included: general safety and monitoring in remote areas; protecting cultural sites; reservation for local Aboriginal use; protecting bird rookeries and channels where fish migrate, and restricting access to areas where there are weeds or a high risk of being attacked by crocodiles (KNPBoM and ANCA, 1996, 107). In the specific instance of the closure of recreational fishing access upstream of the upstream boat ramp near Cahill's Crossing, the reasons given were to limit fishing activity in this part of the River, to reduce the impact on 


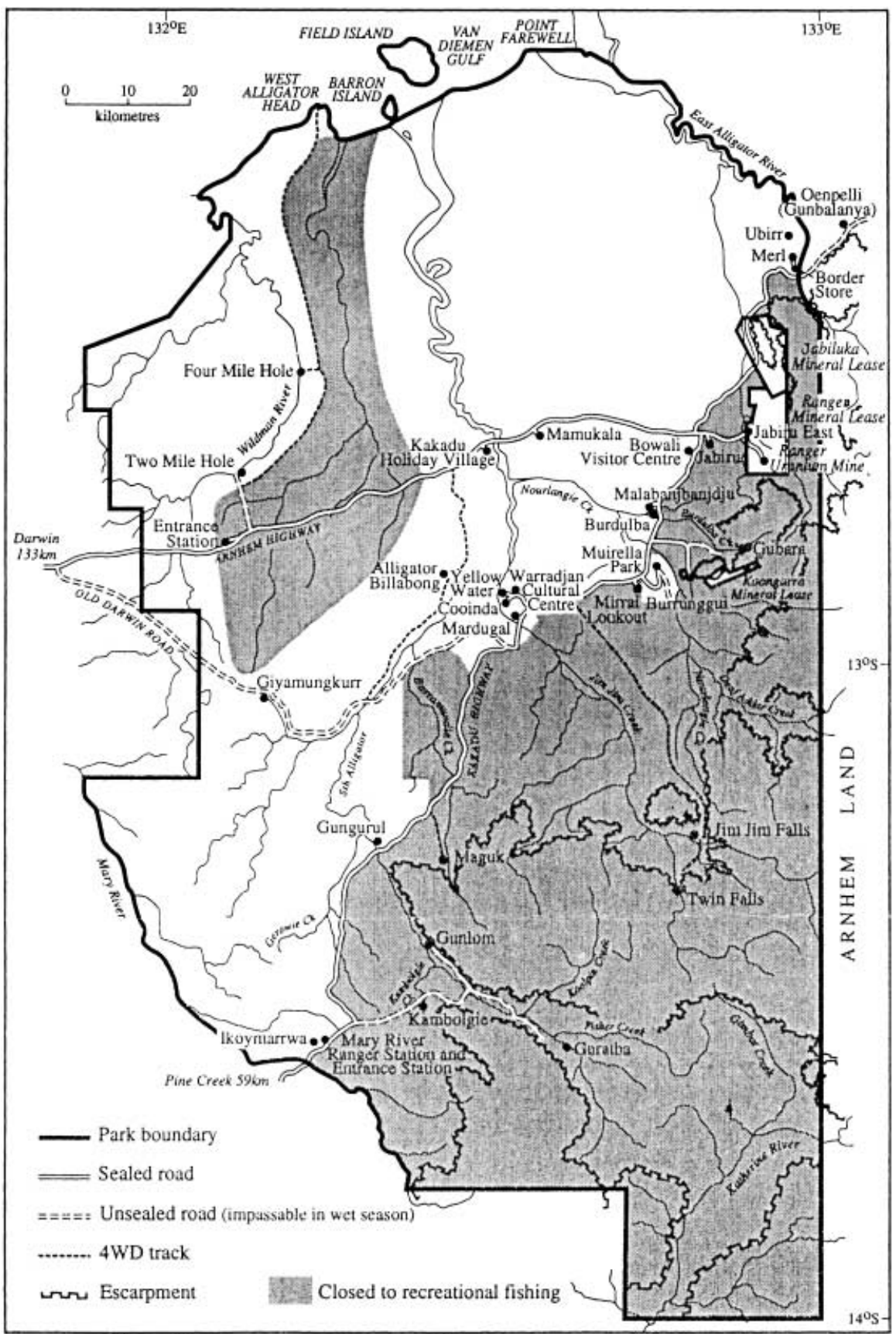

Figure 2 Areas closed to recreational fishing (Source: KNPBoM and Parks Australia 1998, 82). 
other Park visitors, and to limit unauthorised access on to Aboriginal land adjacent to the Park (KNPBoM and ANCA, 1996, 65). The reason given for banning competitions was that the Kakadu Board of Management 'believes that fishing competitions that encourage large numbers of anglers fishing at any one time are inappropriate in the national park' (KNPBoM and ANCA, 1996, 66).

In the same section of the Draft Plan, under the heading, 'Managing Habitats', it was stated that:

A cultural landscape approach based on Bining [sic] knowledge of managing habitats will be adopted for management programs ... Bining will be encouraged and supported to use traditional knowledge and skills relating to managing animals and their habitats. (KNPBoM and ANCA, 1996, 65)

In 1996, for one traditional owner in particular, there was a great deal of concern over the increasing number of fishers accessing the East and South Alligator Rivers. Already at certain periods fisher numbers were at the top of the range of what he considered to be acceptable usage of the area. It was, in his opinion, now time to put fishers on notice of restrictions before the numbers increased even further (Peter Wellings, former Secretary Kakadu Board of Management, personal communication, 1998). The other Aboriginal members on the Kakadu Board of Management supported the assertive stance of the traditional owner from whom these proposals came. The Board felt that traditional owners have a right to make their own decisions about their areas of jurisdiction. However, while other Aboriginal Board members supported the decision of that traditional owner, some were concerned that the process of change was being pushed too fast. From of a total of 97 public submissions to the 1996 Kakadu National Park Draft Plan of Management, 31 representations primarily expressed their discontent over fishing and boating issues. These proposals also generated significant newspaper, radio, and television coverage, particularly in the Northern Territory and in national fishing magazines.
The subsequent controversy over the proposals for fishing management in the Draft Plan highlighted to traditional owners the continued belief in the non-Aboriginal community that Kakadu is public property, not private Aboriginal land as they conceive it. This belief by some sectors of the public is based on the notion that, when traditional owners entered an agreement with the Commonwealth Government to establish the National Park, they relinquished their decision-making rights over that land. It also highlighted to the Board the fact that the government sees public interests as being as important as those of the traditional owners. The community support generated through 'Canberra bashing' among recreational fishing interests also made it clear that, if the Aboriginal members of the Kakadu Board of Management wished to carry through these proposals, there was an increasing need for them to be seen to engage publicly in decision-making and to defend their decisions. For example, the Amateur Fishermen's Association of the Northern Territory's (AFANT) submission to the Draft Plan blamed the decision on a remote bureaucracy that is insensitive to the local Territory lifestyle:

The Kakadu Draft Plan of Management 1996 is a document that deprives all Territorians and visitors to the Northern Territory with (sic) their basic right to enjoy one of Australia's greatest pastimes, Recreational and Sports Fishing. Every 5 years all recreational fishermen and Territorians wait for another set of restrictions placed upon them by a bureaucracy in Kakadu and Canberra.... . AFANT sees this Draft as a negative step in the reconciliation process between recreational fishermen and the Aboriginal communities. ANCA must take into account the Northern Territory lifestyle when managing the park and obviously this has not happened in this instance. $(1996,18, \mathrm{i})$

Throughout the public debate about the proposals in the Draft Plan, it was the non-Aboriginal Secretary to the Board of Management who 
presented the public face of the Board. The traditional owners in Kakadu are often reluctant to stand in the front line of criticism from other stakeholders and, when they do, they prefer to operate in a manner that avoids confrontation. The burden of communicating the practices and priorities of the local Aboriginal jurisdiction to non-Aboriginal parties in Kakadu falls, more often than not, to those few Aboriginal people who have the necessary confidence and bicultural skill to operate successfully within the Park institutional structure. For these people the ceaseless demands placed upon them to represent the rest of the Aboriginal community and interpret their decisions to a hostile public are both onerous and personally draining. It is to a large extent for these reasons that the task is generally avoided. Yet, by choosing not to defend their decisions personally, traditional owners can either be targeted as unaccountable or dismissed as having been manipulated. Moreover, the fishing lobby can then portray the decisions with which they are unhappy as being those of people whom they characterise as manipulative white advisers, such as the Board Secretary or the National Park Manager.

\section{Concepts of land and sea}

Among the non-Aboriginal Australian population generally, there is a strong belief in the communal ownership of both fish stocks and waterways and in the need for government to regulate this (Keen, 1984-1985; Jackson, 1995). As one fisher (personal communication, 1998) from New South Wales commented to me:

It might be my land, but it's not my river and my fish. Nobody should be allowed to own rivers. I think rivers, the ocean and the beaches should be everybody's... water has a more recreational thing about it.

Currently in the Northern Territory, exclusive rights to fish and to water belong to the 'community as a whole' and to no one person or group specifically (Pyne, 1996, 80). However, it is only the relatively recent history of European State-controlled landscape construction that has provided the foundations for an 'elemental distinction between land and sea' in Western culture (Jackson, 1995, 87). In Europe, before the seventeenth century, locally-based heritable sea tenures and marine rights were widespread in communities along the coastal fringe (Sharp, 1996). Likewise, the customary territory of coastal Aboriginal peoples in Australia is made up of a combination of land and sea (Jackson, 1995; Cooke and Armstrong, 1998). Palmer, writing about Yolngu ownership and use of the seas along the coast of northeast Arnhem Land east of Kakadu, stated that:

The principles of local organisation reflect the balance between these two environments. An estate is made up of both land and sea and myths relate to both ... any separation of land and sea arbitrarily divides a territory into two parts. It is almost inconceivable to a Yolngu that such an act of division could be accomplished. Yet, according to European Australian law enacted in the Northern Territory, this is exactly what has happened. (1984-1985, 354-355)

As is the case for their land, the sea for coastal Aboriginal people is something that must be respected and cared for - it is unequivocally part of their country. 'Disturbance of sacred features in the sea, such as reefs and tides, can lead to illness, death, storms, and a change in the availability of marine species' (Jackson, 1995, 90).

Similarly, in Kakadu National Park, marine and freshwater areas and the aquatic species contained within them are treated by Aboriginal peoples as integral to their customary estates and identities. Many people in the Kakadu region refer to themselves as either 'saltwater' people or 'freshwater' people. One senior traditional owner, the late Bill Neidjie (personal communication, 1998), discussing his concerns about recreational fishing along the East Alligator River, explained that '[a]ll along river all this Dreamtime, this water running down sea, Dreamtime story'. Berndt and Berndt (1970, 27-28) wrote that it is the barramundi fish heading to the sea that, in some local clan narratives, 
are responsible for the creation of the East Alligator River and whose actions stipulate taboos and prohibitions on the use of that river. Tacon $(1989,313)$ also examined the various creation stories that surround the East Alligator River. He found that the creator beings are referred to in different versions as the Ancestral Barramundi fish, the Rainbow Serpent and a mythical woman parting her legs and releasing a rush of water.

Spencer (1928) wrote that, for the people of the 'Kakadu tribe', there are extremely elaborate restrictions with regard to food generally and that this is related to totemic beliefs which are bound up with increase ceremonies. Spencer $(1928,128)$ linked fish with beliefs about the spiritual conception of children where, in many cases, it is a fish imbued with the child's spiritual essence that will be caught by the father of the future child, and that fish will be the child's totem. While the elaborate food restrictions referred to by Spencer may no longer be operative, fish continue to be viewed culturally, as well as economically, as an important resource by Bininj in the region. As do the non-Aboriginal fishers, Bininj like going fishing to relax and to enjoy themselves. However, for Bininj, fish and fishing constitute more than a recreational activity. As well as being food, fish, as discussed above, are also permeated with totemic essences.

The late Mick Alderson (personal communication, 1998), a senior traditional owner and the former Chair of the Kakadu Board of Management, explained to me his beliefs and ideas on what constitutes proper fishing practice:

Bininj catch fish and go home and cook them. For some people that is their totem they respect these animals. If you catch them they need to be eaten, fish, turtle or crocodile. Bininj know that in October the fish are weak and bony, they don't hunt them. Bininj fish for a feed, for Balanda [non-Aboriginal people] it is a sport. They shouldn't be using fish as a sport. Trapping and stressing them out. People here worry in October/November. Why go out and fish when the fish are sick?
When food gathering there are different times and ways to do it. We are closing areas for reasons not to hurt people. We don't force fish ... Fish are half dead anyway when you catch them. There should be no catch and release fishing except with undersized fish. The rangers here are starting to learn from us; what to do, when to do it, how to do it.

For many Bininj in Kakadu National Park fishing is part of a lifestyle of hunting. They generally fish from the bank with a handline and the preferred species for many people is not barramundi, but catfish, saratoga, black bream or turtle. A senior traditional owner (personal communication, 1998) explained that:

We fish to catch food. Also goanna and turtle. We look at the whole food chain, the whole experience. Don't waste any part. Look after country and it will look after you. Don't kill everything. Get enough for the table.

This Bininj sense of ethics and protocols in relation to fisheries management is, of course, based on idealised principles of appropriate behaviour. Like any principles they are not immutable and they change over time and according to different situations. Moreover, as Johannes wrote about Indigenous marine conservation systems:

... environmentally destructive practices coexisted, as in most societies, with efforts to conserve natural resources. But the existence of the former does not diminish the significance of the latter. $(1978,355)$

Johannes $(1978,356)$ pointed out that, in Indigenous coastal societies in Oceania, customary principles have suffered under the breakdown of the completeness of these traditional conservation systems caused by the introduction of money economies, the breakdown of traditional authority, and the imposition of new laws and practices by colonial powers. Jacob Nayinggul (personal communication, 1999), a senior traditional owner for the land including part of the East Alligator River, explained his views on the management of recreational fishing in the area: 
You can't stop it. People don't like it when you stop them doing something they have been doing a long time. Some Bininj are the same. Just last week an old man passed away. We had his funeral on Sunday. That man used to walk all this country from here to the Border Store, fishing, hunting, everywhere. I asked people here not to fish that country until after the funeral, after smoking, after dirt has been thrown in the water to cleanse things, until it is all completed. The old people used to tell me to wait one full wet season for the rain to clean the area off, his footprints, camp ashes. Even to rub red ochre around all the tree trunks to mark respect through that area. But people here don't listen. They were out fishing, shooting geese before the funeral even. I go around and growl people but they don't seem to care any more. Now that is a better reason to stop fishing for a while than a complete stop. Balanda too.

We got cultural rules for using that river all right. Strong ones. But sure we used to have real strong law on using that river back when there was no Balanda. Sure there were a few buffalo hunters but they were too busy to beat the Wet [season] to fish. But now full of Balanda sports fishing for barra over the top of Bininj law.

It a big story this fishing one. People have to talk about it, traditional owners, Parks, researchers. I don't think we can stop recreational fishing it has been going on too long. Bininj law will be finished. We all need to look at this, traditional owners and Parks. I mean the words are there to protect Bininj way of doing things but not the action. Big story.

\section{'Commonsense' nature and resources}

It can be seen then that, for Bininj, fish constitute more than a natural resource in the Western sense of resource management. It follows that Bininj management of fisheries, riverine environments and coastal areas will incorporate Bininj perspectives and beliefs in a way not necessarily commensurate with Western notions of resource management (Johannes, 1978). Likewise, Western resource managers operate and justify their management decisions within their own 'commonsense' notions of resources. However, while Bininj 'commonsense' views reflect socio-physical interrelations and a shared identity between people, land and resources, the Western 'commonsense' views are based on a belief in a reified external reality from which one can measure the degree to which management decisions conform with an objective truth. In 1997, when Robert Hill, then the Federal Minister for the Environment, spoke to the Kakadu Board of Management on the issue of fishing management, he maintained that, in order to put in place the proposed management changes, the Board needed rational reasons to justify the decisions that they made (Peter Wellings, former Secretary Kakadu Board of Management, personal communication, 1998). Hill was echoing the view of a politically powerful fishing lobby that relies on its own culturallysanctioned institutions of conservation science, and expects decisions to be based on scientific proof that fishing is or is not causing detriment to fish stocks.

In contrast to this scientific rationalist approach to decision-making and resource management, Bininj recognise that it is the primary right of the traditional owners of the fishing areas concerned to make decisions on the management of their country. One senior traditional owner, the late Mick Alderson (personal communication, 1998), commenting on the fishing lobby's outcry over proposed fishing management, stated that 'They think this Park is for everybody. This is Aboriginal land. They should respect the wishes of the owners. They don't have to give a reason.'

However, intensive lobbying of Commonwealth Ministers by Territory recreational fishing interests, as well as public meetings to protest proposed changes to fishing restrictions within the Park, resulted in the revision of the Board's original draft proposals (in effect the maintenance of the status quo). The Board revised the Draft Plan, and the Kakadu National 
Park Plan of Management (KNPBoM and Parks Australia, 1998, 83) refers instead to plans to undertake further research to monitor and gather information on recreational fishing in the Park. This will include monitoring fishing impacts through fisheries surveys and consultation with interest groups.

This outcome essentially conforms to a Western scientific epistemology that naturalises 'nature' and imagines it to be an empty space free of social relations. Canadian geographer Bruce Willems-Braun, writing on the politics of nature in (post)colonial British Columbia, examined the Western commonsense categories of 'nature' and 'resources' whereby nature is made to appear as an empty space to be accounted for, and where the authority of Western science becomes the basis for moral and political rationalities of resource use and conservation. In this schema, Indigenous peoples' concepts of nature, which do not recognise a nature/culture binary, which incorporate an integrated social system and which are linked with local cultural and political contexts, are displaced in favour of the authority of the 'nation' or the 'public' to speak for and to manage an unmediated nature. Willems-Braun wrote that:

...this abstraction displaces discussions of authority from questions of territory, tenure, and rights of access (and their constitutive colonial histories) ... . By staging the nationstate as accomplished rather than continually articulated [management regimes] are rendered transparent and thus 'commonsense'. (1997, 11)

Willems-Braun examined the epistemological basis of both Western extractive resource use and environmentalism and found that these apparently oppositional concepts are in fact complementary:

Nature is never a 'pure' category. It is always invested with, and embedded in social histories. From an anti-colonial perspective, extractive capital and environmentalism are in many ways mirror images, sharing common elements of a culture of nature. Taken together these rhetorics constitute a 'natural' field and divide it between opposing non-native interests. (1997, 25)

The product of colonial histories is a 'natural' space that authorises 'certain voices - resource managers, bureaucrats, nature's defenders - to speak for nature' (Willems-Braun, 1997, 11; see also Sullivan, 2000). Thus the authority of the Western culture of science allows a 'commonsense' view of what constitutes resource management to prevail.

\section{Fishing lore}

A large number of non-Aboriginal fishers in Kakadu can be characterised as sports fishers. According to one Northern Territory fisher (personal communication, 1998), while fishers in the Northern Territory target barramundi, they rarely eat it. He explained 'I don't like barramundi, it is an over-rated fish, unless I take it from the salt water...the emphasis on fishing is on the skill and experience necessary to be an effective fisher'. Moreover, he stated that the catch and release ethic is so strong amongst Northern Territory fishers that, 'If I want to take a fish for the table I'd have to fight with my kids. And my kids aren't much different to others. They all have the same attitude.' He believes that this is something fishers:

... have to try to get traditional owners to understand — we put it back [Similarly, the slogan on AFANT rugby tops reads "put a barra back']. It is a hard thing for us to get across to them. We don't keep them. In their culture fish are caught and they're dead.

Another fisher (personal communication, 1998) in Kakadu told me with pride that he had caught and released 700 barramundi in his six-week stay at Yellow Water billabong in the central region of Kakadu National Park.

In 1985, Dick Eusson prepared a submission on behalf of AFANT on why people should be allowed to fish in the Kakadu National Park. The submission was prepared at the request of 
the then Director of the Australian National Parks and Wildlife Service, Professor Ovington. He asked recreational fishers to justify why they should be allowed to fish in Kakadu National Park. Eusson's $(1985,2)$ submission argued that 'man's primitive instincts are to hunt and fish' and, while the need to hunt for food and clothing is no longer the motivation in many countries, this has been replaced by a keen sense of sportsmanship which, in many cases, has been instrumental in game conservation.

Similarly, Campbell (1989) examined the sub-culture of sports fishing in his paper 'Fishing Lore'. In his Californian study, he found that white fishers use fishing lures to emulate natural baits (in physical appearance or in movements), where the intent is to recreate nature through a process of 'lure surgery' $(1989,83)$. Technologies such as sonar fish finders are used to allow fishers greater access to the realm of nature. Campbell argued that 'the sportsman is characterised by his privileging of nature and his attempt to engage it at what he perceives to be its level. Fishing, for the sportsman, is concerned with his ability to model nature' (1989, 86). Campbell, examining the fishing practices of a variety of socio-economic groups, noted that 'fishing practices are uniquely suited to reveal contradictions in the natural/cultural oppositions and hierarchy' (1989, 77). Analysing the tendency for Western culture to privilege the natural over economic and social forms, he wrote:

The concept of the 'sportsman' encourages the fishermen to adopt increasingly 'natural' methods in blurring the man/fish polarity .... By assuming natural 'methods', the sportsman believes himself to be reaffirming nature by imitation, when in fact he merely tends to control it. The sportsman does not catch fish to keep them. Proponents of the "catch and release' method attest to the importance of catching fish, that is, of rendering them powerless, by distinguishing between catching and killing fish. (1989, 86).

Campbell argued that the manipulation of nature is the fundamental principle of sports fishing
(1989, 87). Moreover, he suggested that, in the social discourse of sports fishing, where white Californian fishers often travel huge distances at great cost to fish, the capitalist values of individuals who, in reality, have quite high status in the socio-economic hierarchy, are inverted. Campbell suggested that the mask of the sportsperson allows the white fishers to readily accept a non-linear relationship between their labour and production and in doing so they take on the character of fake-primitives in their performance (1989, 88).

While sports fishing methods of catch and release fishing are argued by proponents to be best environmental practice, the fishing methods practised by Aboriginal people within Kakadu, who are fishing for food, are often asserted by non-Aboriginal fishers to be illegitimate. For fishers, the mask of the 'natural' and the power of western conservationism have effectively removed their recognition of their own cultural practices. Since recreational fishers do not catch fish to keep them, they retain the power and moral authority attributed to pure unmediated nature. In 1994, a prominent Northern Territory fishing writer, Alex Julius, expressed amazement in his weekly fishing column at his observation of an Aboriginal fishing practice:

There's good news and bad news about the culvert next to the South Alligator River. It seems hundreds of barra about $15 \mathrm{~cm}$ long were congregating on both sides of the culvert - a very positive sign for the future. But then a car load of local Aborigines came in and wiped the lot out with cast nets. It seems they're allowed to do this in Kakadu or anywhere else in the Territory. I could understand if they were using traditional methods such as spearing fish, but clearing out significant numbers of this year's barramundi crop with Taiwanese made cast nets is not on. At how many other places in Kakadu is this practice taking place undetected? (Julius, 1994, 19)

This non-Aboriginal fisher's criticism of this incident assumes the superiority of the sports 
fishers own 'natural' fishing methods to the extent that he feels justified in criticising the 'unnatural' practices of others. Referring to this incident, one fisher (personal communication, 1998) stated his belief that in Kakadu 'there's a lot of cake and eating going on .... They want to protect wildlife and then the Aborigines are allowed to shoot anything that moves from the back of Toyotas, like geese any time of the year'. From this perspective 'genuine' Aborigines are somehow located back in nature, 'as undeveloped primitive precursors to modern culture' (Willems-Braun, 1997, 24) who do not use technology such as nylon fishing twine, cast nets, guns and motor vehicles to hunt their food resources. Moreover, the fact that local Aborigines in Kakadu do use this technology is seen as obviating their rights to be 'traditional' users of their estates, and their ability to maintain the resources of those estates. In these instances, the social context in which Bininj use and manage their resource base is ignored or dismissed, while the social context of sports fishers is implicitly elevated as the universal benchmark to guide the relations between humans and what is imagined to be an unmediated 'natural environment', and recreational fishers continually assert their authority as responsible maintainers of natural resources.

\section{Negotiating land and resource use}

In their negotiations with non-Aboriginal Park users, the power of these 'naturalised' lay and scientific natural resource management epistemologies and ideologies is so dominant that Aboriginal traditional owners working within the Park institutions will often choose to construct their management arguments and provide 'reasonable' justification for their decisions within this dominant framework. Arguments are adopted that fit in with the rationale of fishers and conservation management professionals, leaving other considerations that matter in the Aboriginal domain unexplained. For example, the argument set out by the Kakadu Board of Management in the 1996 Draft Plan of Management that fishing competitions are not appropri- ate in a national park appeals to particular conservationist rationales. However, arguments such as this when used by traditional owners to justify their own decisions are easily exploited by disgruntled stakeholders, especially those as politically powerful as the fishing lobby. They focus on the contradictions in the argument of this 'nature-based rationale' by pointing out that Park management allows the domestic cattle owned by local Aboriginal people and wild horses to roam in 'wilderness' areas of the Park. AFANT, in their submission to the Draft Plan, responded in outrage to suggestions that commercial exploitation of feral animals in a national park by Aboriginal people should be tolerated while what they see as their legitimate right to free and open access to recreational fishing in Kakadu is being denied. Out of a total of 97 submissions to the 1996 Kakadu National Park Draft Plan of Management, ten addressed the combination of fishing, boating and the potential commercial use of native or introduced wildlife by Aboriginal people.

Alternatively, in their negotiations with nonAboriginal people who imagine the common reference point to be an objective scientific truth, Bininj may choose to remain silent, not in agreement, but in the absence of a space and discursive position from which to speak effectively and to respond (cf. Christie and Perrett, 1996). In Bininj negotiations, attention is typically paid to the landowners' primary rights to speak for country and resources, while at the same time respectfully recognising the perspective of others. This 'requires tact, patience and time' (Christie, 1992, 25). In this way, the negotiation practices between land-owning groups involve attention both to the legitimacy of individuals representing groups of others, and 'an acceptance of the rights of participants to speak for their own territories - and for the people, resources, cultures and histories of those territories' (Christie and Perrett, 1996, 59). It is a style of negotiation in which ideological and other differences are seen as constituting partialities of ex-centric perspectives, not competition for an objective truth (Christie, 1992). This process 
of knowledge production is generated selfconsciously out of, and through attention to, social relationships, rather than from a belief in the existence of an objective reality waiting to be 'discovered'.

The recreational fishing lobby in general denies recognition to Aboriginal land owners of their primary rights to speak for country and resources in Kakadu. The 'bottom line' for the fishers' argument is that Kakadu's waterways and fisheries belong to 'the community as a whole'. However, the rational 'commonsense' approach and the 'bottom line' of the nonAboriginal fishers and the Western resource managers who are entrusted to manage resources fail to acknowledge the constructedness of their own 'socially constituted knowledges' (Castree, 2001,10 ), and this hinders any negotiation that challenges Western epistemic commitments (Verran, 1998). In the Western liberal public sphere, the model of stakeholder negotiations most often employed in national park and natural resource management aims to balance competing interests through a rationalist appeal to a 'common good' and to disengaged reason, an appeal that lacks both the recognition of ontological difference and the unequal power of symbolic privilege (Young, 1995, 141). In Kakadu, third-party interest groups, such as the tourism and fishing industries, which are outside the Park's formal joint management arrangements, assert their own ideologies and environmental management visions for the Park and complicate the joint management situation by demanding even further compromises by the Aboriginal traditional owners.

\section{Negotiating difference and commonality}

The process of negotiation of different interests does not have to be bounded by confrontation and appeals to disengaged reason. Young (1995, 149) has suggested that, in cross-cultural situations, the narratives of situated knowledge which include the expression and extension of shared understandings, where they exist, and the offering and acknowledgment of unshared meanings, are a useful tool of negotiation. She wrote that, within the pluralist politics of divergent cultural assumptions:

... narrative can serve to explain to outsiders what practices, places or symbols mean to the people who hold them. Values, unlike norms, often cannot be justified through argument. But neither are they arbitrary. Their basis often emerges from the situated history of a people. Through narrative the outsiders may come to understand why the insiders value what they value and why they have the priorities they have [as well] listeners can learn about how their own position, actions and values appear to others from the stories they tell. $(1995,148)$

Fishers' narratives that engage with people and place respectfully are also more likely to be effective in negotiations with traditional owners. In contrast to the sometimes aggressive style of the AFANT representative, the presentation to the Board of Management by a local Jabiru resident (the mining town located on a separate lease within the Park), focussed on the relationships between Jabiru residents who like to fish and the traditional owners, and how these would be affected by the proposed fishing restrictions. He explained that the fishing issue was a very emotional issue among Jabiru residents and that it had created much animosity. He said people go fishing to enjoy the park not just to catch fish, and explained that Jabiru residents like to go fishing and to enjoy the safety of the upstream area of the East Alligator, because it is a place where they can go with their families. The arguments for the quiet enjoyment of the river and for fishing as family recreation were compelling to many of the Aboriginal Board members (Peter Wellings, former Secretary Kakadu Board of Management, personal communication). The traditional owners are proud of the fact that many tourists who come to Kakadu are thrilled to have a chance to catch a barramundi and they enjoy sharing their country with those who may not otherwise have these opportunities in their everyday lives. For example one Bininj male (personal communication, 
1998) commented about recreational fishers in the Park:

They good people too. Family mob come and talk to you, want to ask you about country. Some good people too. Have a beer in the pub with them. Tell them about fishing and they listen to you. We tell them there are spots they can't go - sacred site or just for Bininj. They find it hard to understand.

Their assertion of primary responsibility for country and land ownership does not mean that the traditional owners are not prepared to negotiate and accommodate other interests. Bininj are generally amenable to sharing their country with others, as long as the traditional owners' rights are respected.

\section{Conclusion}

While there are significant differences as well as similarities in the various conceptualisations of fishing as a part of local lifestyles, it is in the discourse of resource use and management that Bininj and non-Aboriginal knowledges appear the least compatible. While Western science conceives of fish as a resource to be managed sustainably, Bininj view fish and their harvest not only as a significant source of food, but also as part of a wider system of interconnected socio-physical relationships and identity. Salt and freshwater resources in Kakadu National Park are part of Bininj social identity, and Park management will increasingly have to acknowledge that the issues that pervade the Kakadu domain in relation to land are the same for aquatic areas.

The management of recreational fishing is an issue that raises crucial questions about communication and negotiation across an ontological divide of land considered as country through an inter-subjective social reality, and land and resources cared for as 'other' in the objective reality of scientific natural resource management. Finding ways of answering these questions will involve a preparedness on the part of non-Aborigines to listen to, reflect on and respect the culturally specific rights of Aboriginal traditional owners whose jurisdiction encompasses the use and management of the resources contained within their estates (cf. Ayre, 2002). Unless these competing management and negotiation styles are acknowledged and addressed by non-Aboriginal Park managers and other Park users it is an ontological divide which will continue to impede the process of negotiating co-operative Aboriginal and non-Aboriginal management and land use in Kakadu National Park. Under Australian law, and in the management rhetoric of the Park's Plan of Management (KNPBoM and Parks Australia, 1998), Aboriginal people are recognised as the rightful owners and managers of Kakadu National Park. However, as the controversy over the management of recreational fishing discussed above demonstrates, a gap remains between the formal recognition of Bininj property rights (which by implication entails de facto recognition of an Aboriginal jurisdiction (see Langton, 2002; Nettheim et al., 2002)) and the existence of a broadly-based political will on the part of nonAboriginal people and their institutional structures to support and engage with the decisionmaking processes and priorities that constitute the Bininj jurisdiction in Kakadu National Park. Clearly, in the case of Kakadu National Park, the successful application of the joint management rhetoric lies in non-Aborigines stepping back and creating the space for Aboriginal land owners to make decisions about the management of country according to their own systems of governance and priorities for natural resource management, while, at the same time seeking, when they decide it is required, technical advice and input from those others who have a stake or a role to play in particular aspects of natural resource management in the Park.

\section{Postscript}

The paper is based on fieldwork and interviews which the author carried out in Kakadu National Park between 1997 and 1999. Since this time a series of constructive meetings and discussions aimed a gaining a better understanding of each other's perspectives have taken and continue to 
take place between representatives from the Kakadu Board of Management, Parks Australia and recreational fishing groups.

Correspondence: Dr Lisa Palmer, School of Anthropology, Geography and Environmental Studies, The University of Melbourne, Victoria 3010, Australia. Email: lrpalmer@unimelb.edu.au

\section{ACKNOWLEDGMENTS}

I am indebted to the Kakadu National Park Board of Management, traditional owners of Kakadu, and their families under whose auspices I was able to conduct my research in the period from 1997 to 2000 . I would like to acknowledge and thank my thesis supervisors Professor Marcia Langton, Professor Nancy Williams and Dr. Michael J. Christie who provided guidance and comment on earlier drafts of this paper.

\section{REFERENCES}

Amateur Fishermen's Association of the NT, 1996: Kakadu National Park Draft Plan of Management Submission.

Australian National Parks and Wildlife Service, 1986: Kakadu National Park Plan of Management. ANPWS, Canberra.

Australian National Parks and Wildlife Service and Kakadu National Park Board of Management, 1991: Kakadu National Park Plan of Management. ANPWS, Canberra.

Ayre, M., 2002: Yolngu places and people: taking Aboriginal understanding seriously in land and sea management. Unpublished PhD. Thesis, The University of Melbourne, Melbourne.

Berndt, R. and Berndt, C., 1970: Man, Land and Myth in North Australia: The Gunwinggu People. Ure Smith, Sydney.

Campbell, M.B., 1989: Fishing lore: The construction of the 'sportsman'. Annals of Tourism Research 16, 76-88.

Castree, N., 2001: Socializing nature: theory, practice, and politics. In Castree N. and Braun B. (eds) Social Nature: Theory, Practice, and Politics. Blackwell, Malden, Ma. USA, 1-21.

Chaloupka, G., 1975: Report on Aboriginal traditional landownership of the Alligator Rivers Region. Part 2: landowning groups and their traditional territories. George Chaloupka, Darwin.

Chaloupka, G., 1993: Journey in Time: The World's Longest Continuing Art Tradition. Reed, Sydney.

Chaloupka, G., Kapirigi, N., Nayidji, B. and Namingum, G., 1985: Cultural Survey of Balawurru, Deaf Adder Creek, Amarrkananga, Cannon Hill and the Northern Corridor. Unpublished report to the ANPWS and The Museum and Art Galleries Board of the NT, Darwin.

Christie, M., 1992: Grounded and ex-centric knowledges: exploring Aboriginal alternatives to Western thinking, paper presented to the Fifth Annual Conference on Thinking. Townsville, Australia, 7 July, 14-27.

Christie, M., and Perrett, B., 1996: Negotiating resources: language, knowledge and the search for 'secret English' in northeast Arnhem Land. In Howitt, R., Connell J. and Hirsch, P. (eds) Resources, Nations and Indigenous Peoples; Case Studies from Australasia, Melanesia and Southeast Asia. Oxford University Press, Melbourne, 5765.

Cooke, P. and Armstrong, G., 1998: Ownership and resource use on islands off the Liverpool River, Northern Territory. In Peterson N. and Rigsby B. (eds) Customary Marine Tenure in Australia. Oceania Monograph, Oceania Publications, University of Sydney, Sydney, 178-191.

Duff, G., 1989: Impact of recreational angling in Kakadu National Park, Unpublished report to ANPWS, Canberra.

Eusson, D., 1985: Submission to ANPWS on why people be allowed to fish in the Kakadu National Park Stages I-IIIII. Amateur Fishermen's Association NT, Darwin.

Jackson, S., 1995: The Water is not empty: cross-cultural issues in conceptualising sea space. Australian Geographer 26, 87-96.

Johannes, R.E., 1978: Traditional marine conservation methods in Oceania and their demise. Annual Review of Ecological Systems 9, 349-364.

Julius, A., 1994: Frustrating times for Top End fishos. Northern Territory News (4 March), 19.

Kakadu National Park Board of Management and Australian Nature Conservation Agency, 1996: Kakadu National Park Draft Plan of Management. Parks Australia, Jabiru.

Kakadu National Park Board of Management and Parks Australia, 1998: Kakadu National Park Plan of Management. Parks Australia, Jabiru.

Keen, I., 1975: Report on Aboriginal land-ownership of the Alligator Rivers Region. Part 1: the land-owning groups (clans) and their membership. Ian Keen, Darwin.

Keen, I., 1980: The Alligator Rivers Stage II Land Claim. Unpublished report to the NLC, Darwin.

Keen, I., 1984-1985: Aboriginal tenure and the use of the foreshore and seas: an anthropological evaluation of the Northern Territory legislation providing for the closure of the seas adjacent to Aboriginal land. Anthropological Forum 5, 421-439.

Langton, M., 2002: Ancient jurisdictions, Aboriginal polities and sovereignty. Paper presented at the Indigenous Governance Conference Canberra 3-5 April. Online: http:// www.reconciliationaustralia.org/textonly/info/publications/ governance/speeches.html Accessed: 02-10-15.

Levitus, R., 1982: Everybody Bin All Day Work: A Report to the Australian National Parks and Wildlife Service on the Social History of the Alligator Rivers region of the Northern Territory 1869-1973. Australian Institute of Aboriginal Studies, Canberra.

Merlan, F., and Rumsey, A., 1982: The Jawoyn (Katherine Area) Land Claim. NLC, Darwin.

Nettheim G., Meyers, G., and Craig, D., 2002: Indigenous Peoples and Governance Structures: A Comparative Analysis of Land and Resource Management Rights. Aboriginal Studies Press, AIATSIS Canberra.

Northern Territory Government, 1998: Statehood protects my lifestyle. Sunday Territorian (6 September), 12. 
Northern Territory Government, 1999: Foundations for our future. Sunday Territorian (31 October), 42.

Palmer, K., 1984-1985: Ownership and use of the seas: the Yolngu of north-east Arnhem Land. Anthropological Forum 5, 448-455.

Palmer, L., 2001: Kakadu as an Aboriginal Place: tourism and the construction of Kakadu National Park. Unpublished PhD thesis, Northern Territory University, Darwin.

Pyne, R., 1996: The Administration and management of fish and aquatic life in the Northern Territory. In Sultan, R., Josif, P., Mackinolty, C., and Mackinolty, J. (eds) Ecopolitics IX Conference: Perspectives on Indigenous Peoples Management of Environment Resources, Darwin 1995. Northern Land Council, Darwin, 80-83.

Sharp, N., 1996: Reimagining Sea Space in History and Contemporary Life: Pulling up some Old Anchors. Discussion Paper No. 5, North Australian Research Unit, Australian National University, Darwin.
Spencer, B., 1928: Wanderings in Wild Australia. Macmillan, London.

Sullivan, S., 2000: Getting the science right, or introducing science in the first place? In Stott, P. and Sullivan, S. (eds) Political Ecology. Arnold, London, 15-44.

Tacon, P., 1989: From Rainbow Snakes to 'x-ray' fish: the nature of the recent rock painting tradition of Western Arnhem Land, Australia, Unpublished PhD thesis, Australia National University, Canberra.

Verran, H., 1998: Re-imagining land ownership in Australia. Postcolonial Studies 2, 237-254.

Willems-Braun, B., 1997: Buried epistemologies: the politics of nature in (post) colonial British Columbia. Annals of the Association of American Geographers 87, 3-31.

Young, I., 1995: Communication and the other: beyond deliberative democracy. In Wilson, M. and Yeatman, A. (eds) Justice and Identity: Antipodean Practices. Allen and Unwin, Wellington, 134-152. 